\title{
Surface activity of Corophium volutator: A role for parasites?
}

\author{
Jacob Tørring Damsgaard, Kim N. Mouritsen, K. Thomas Jensen* \\ Department of Marine Ecology, Institute of Biological Sciences, University of Aarhus, Finlandsgade 14, DK-8200 Aarhus N, Denmark
}

Received 22 September 2004; received in revised form 5 April 2005; accepted 5 April 2005

Available online 8 June 2005

\begin{abstract}
In soft-bottom intertidal habitats, the normally infaunal amphipod Corophium volutator is often found active on the sediment surface during low tide, exposed to desiccation and shorebird predation. Here we examine whether such risky behaviour is related to parasite infections. Surface-active and buried C. volutator were collected during a low tide period in the Danish Wadden Sea, and the infection patterns of the two groups were described in relation to sex and size. Surface-active males and females were more heavily infested by microphallid trematodes (four species) than buried specimens of the same sex and size class. Although the density of surfaced amphipods decreased as a function of exposure time, the mean parasite load of those that remained on the surface increased. A narrow size-specific parasite intensity threshold above which the amphipods were always surface active did not exist: heavily infected individuals were also found buried in the substrate. Although likely to be beneficial to the parasites, this suggests that the behavioural alteration is a side-effect of the infections rather than a consequence of direct parasitic manipulation. Besides the presumed mortality associated with the parasite-related surface activity in a range of size-classes, the intensity-size frequency distribution indicated that larger and hence heavily infected hosts are removed from the population. Together it demonstrates that microphallid trematodes impact the population dynamics of $C$. volutator.
\end{abstract}

(C) 2005 Elsevier B.V. All rights reserved.

Keywords: Corophium volutator; Field observations; Microphallidae; Surface behaviour; Trematodes

\section{Introduction}

Biota on intertidal mudflats is typically exposed to considerable fluctuations in environmental conditions during the tidal cycle. Burrowing and tidal migration are strategies used by animals to avoid unfavourable

\footnotetext{
* Corresponding author.

E-mail address: kthomas@biology.au.dk (K.T. Jensen).
}

conditions, but some individuals seem to exhibit risky behaviour by remaining on the sediment surface under such conditions. So, specimens of the infaunal amphipod Corophium volutator are frequently found crawling on the sediment surface of tidal flats at low tide (Watkin, 1941; Meadows and Reid, 1966; Fish and Mills, 1979), exposed to desiccation and an increased risk of predation by shorebirds (Hicklin and Smith, 1984; Peer et al., 1986; Boates and Smith, 1989; Matthews et al., 1992). The amphipods' reproductive 
behaviour could be one explanation for this, because males typically crawl on the surface searching for burrows inhabited by receptive females (Watkin, 1941; Meadows and Reid, 1966; Fish and Mills, 1979). Alternatively, surfacing specimens could be controlled by parasites that thereby enhance the probability of infecting their shorebird final host through trophic transmission (McCurdy et al., 1999a). Similarly, surfacing behaviour of bivalves has often been explained by the presence of parasites interfering with their ability to burrow (Lauckner, 1983; Bowers et al., 1996; Thomas and Poulin, 1998; Jensen et al., 1999; Mouritsen, 2002).

In the present study, we assess the role of digenetic trematodes in causing surface activity of $C$. volutator. These parasites represent a ubiquitous element of littoral faunas and are widespread and abundant in populations of C. volutator (Lauckner, 1987a). In the Danish Wadden Sea, the mud snail Hydrobia ulvae serves as first intermediate host for a wide range of microphallid trematodes, and C. volutator is used as second intermediate host in which the parasite larvae encyst as metacercariae. Various shorebirds serve as final hosts reached by trophic transmission. The shorebirds occurring in the Danish Wadden Sea are mostly spring and autumn migrants (Meltofte et al., 1994), which limits the temporal overlap between parasites and their final hosts. Such circumstances may favour the development of parasitic manipulation of host behaviour, such as increased surface activity, which enhances the probability of parasites being transmitted (Dobson, 1988; Poulin, 1994). Indeed, several parasites with complex life cycles are known to control intermediate host behaviour to facilitate consumption by potential final hosts (see reviews by Bush et al., 2001 and Moore, 2002). In accordance, studies by McCurdy et al. (1999b, 2000) indicate that male and female $C$. volutator harbouring infective stages of the trematode Gynaecotyla adunca spend more time crawling on the surface than uninfected individuals, and Mouritsen and Jensen (1997) have shown a similar pattern in $C$. volutator exposed to microphallid trematodes in the laboratory.

In this study, surface-active and burrowed C. volutator on a Danish Wadden Sea mud flat were compared with respect to sex, size, prevalence and infection intensity of microphallid trematodes to test the hypothesis that individuals crawling on the sedi- ment surface on ebbing tide are more heavily infected than burrowed individuals. The C. volutator population from our study site hosts at least four species of microphallid trematodes: Microphallus claviformis (Brandes, 1888), Maritrema subdolum, Microphallidae sp. no. 15 (Deblock, 1980) and an unknown Levinseniella species.

\section{Materials and methods}

The study was carried out on an intertidal Corophium bed (Mouritsen et al., 1997) in the Danish Wadden Sea near Ribe Kammersluse $\left(55^{\circ} 21^{\prime} \mathrm{N}\right.$, $8^{\circ} 39^{\prime}$ E) on 25 September 2000. The density of adult Corophium volutator $(>4 \mathrm{~mm}$ ) on the experimental plot was 13000 individuals $\mathrm{m}^{-2}$ in September (Fredensborg, 2001). Within a $20 \times 20 \mathrm{~m}$ area located $100 \mathrm{~m}$ seaward from the high-water mark, the number of surface-active specimens of $C$. volutator were counted in ten $1-\mathrm{m}^{2}$ plots, and subsequently individually collected with tweezers, during four 40 -min periods separated by $20 \mathrm{~min}$ and starting when the water had receded from the investigation area (i.e. 30-70, 90-130, 150-190 and 210-250 min after high tide). During each sampling event, it was ensured that counts and collections were carried out in previously undisturbed parts of the investigation area. To compare the infection characteristics of surface-active and buried amphipods, thirty $50-\mathrm{cm}^{2}$ core-samples were collected between 180-270 min after high tide, and sieved through a $500 \mu \mathrm{m}$ screen. Adult individuals were picked at random from the benthic samples. To eliminate predator-interference, waders were actively kept out of the area during the entire sampling period by means of gestures and yells.

The collected animals were preserved in neutralised $4 \%$ formaldehyde and afterwards stored in $80 \%$ ethanol. In the laboratory, the length of each individual was measured from rostrum to telson, and the amphipods were sexed. All adults $(>4 \mathrm{~mm}$ in body length) were subsequently dissected and examined for the presence of microphallid metacercariae using a microscope $(100 \times)$. Maximum and minimum diameter of each encysted parasite was measured to the nearest $10 \mu \mathrm{m}$. The parasites were identified according to Deblock (1980) and Lauckner (1987b). Ovoid 


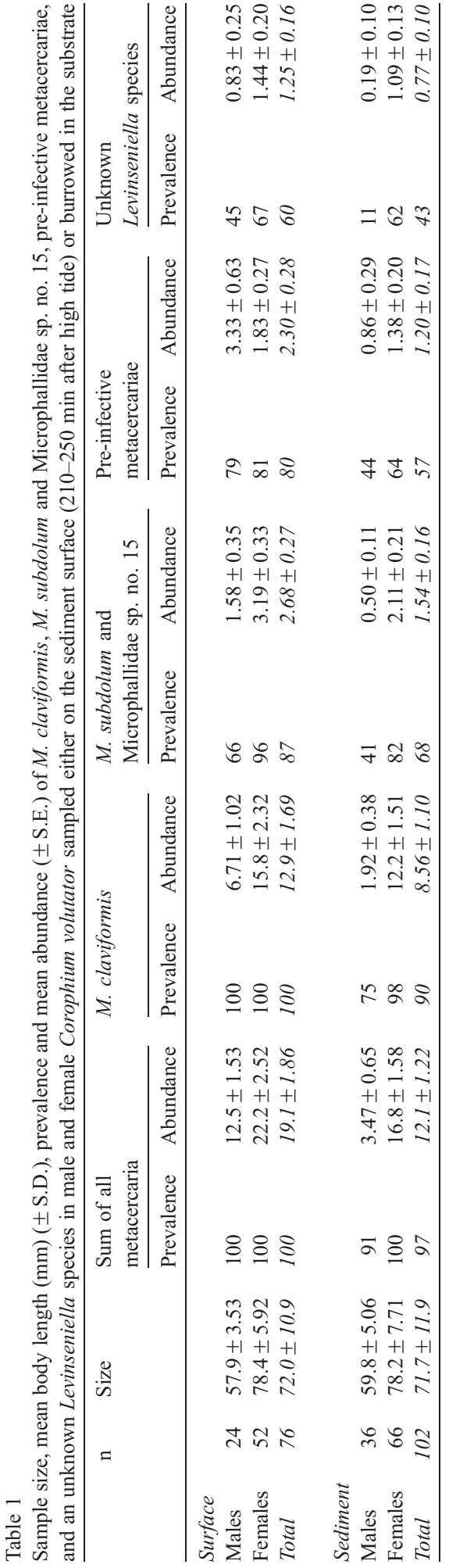

cysts with a diameter between 160 and $210 \mu \mathrm{m}$ were considered metacercariae of Microphallus claviformis. Spherical cysts with a diameter between 160 and $210 \mu \mathrm{m}$ were considered metacercariae of Maritrema subdolum or Microphallidae sp. no. 15. Cysts larger than $220 \mu \mathrm{m}$ in diameter were considered to be metacercariae of Levinseniella sp., and cysts with a maximum diameter of $150 \mu \mathrm{m}$ and no or a thin outer layer were, in addition to unencysted mesocercariae, classified as pre-infective metacercariae.

Following Margolis et al. (1982), we calculated parasite prevalence (proportion of infected individuals) and mean parasite abundance (mean parasite load of infected plus uninfected individuals) for each of the five samples of amphipods.

Both parametric and non-parametric tests were used to analyse the data. All tests were two-tailed using the $5 \%$ level of significance. All analyses were conducted using the statistical package SPSS for Windows (release 10.0).
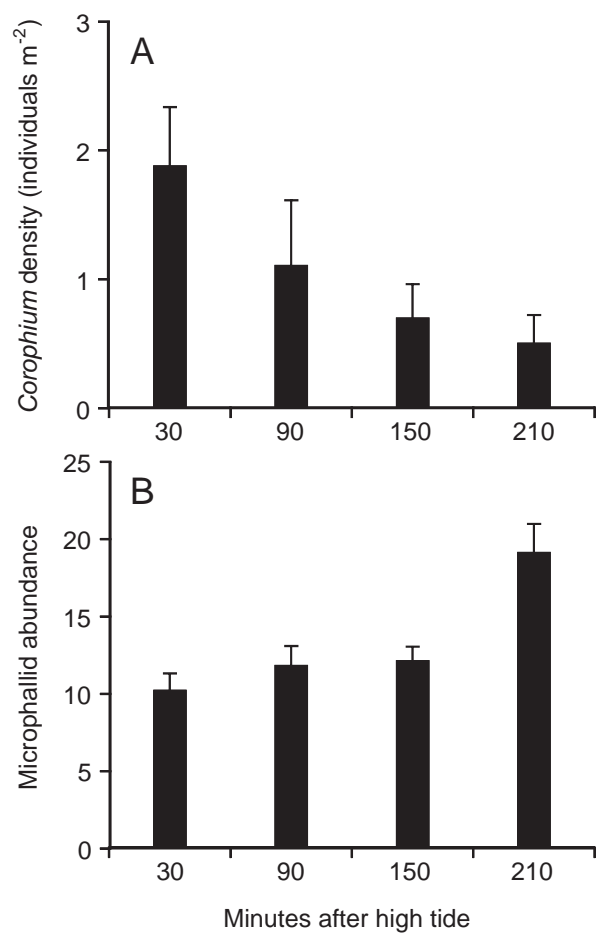

Fig. 1. (A) Mean density (ind $\left.\mathrm{m}^{-2}\right)( \pm$ S.E.) of Corophium volutator and (B) mean abundance ( \pm S.E.) of microphallid infections in C. volutator collected $30-70,90-130,150-180$ and $210-250 \mathrm{~min}$ after high tide. 


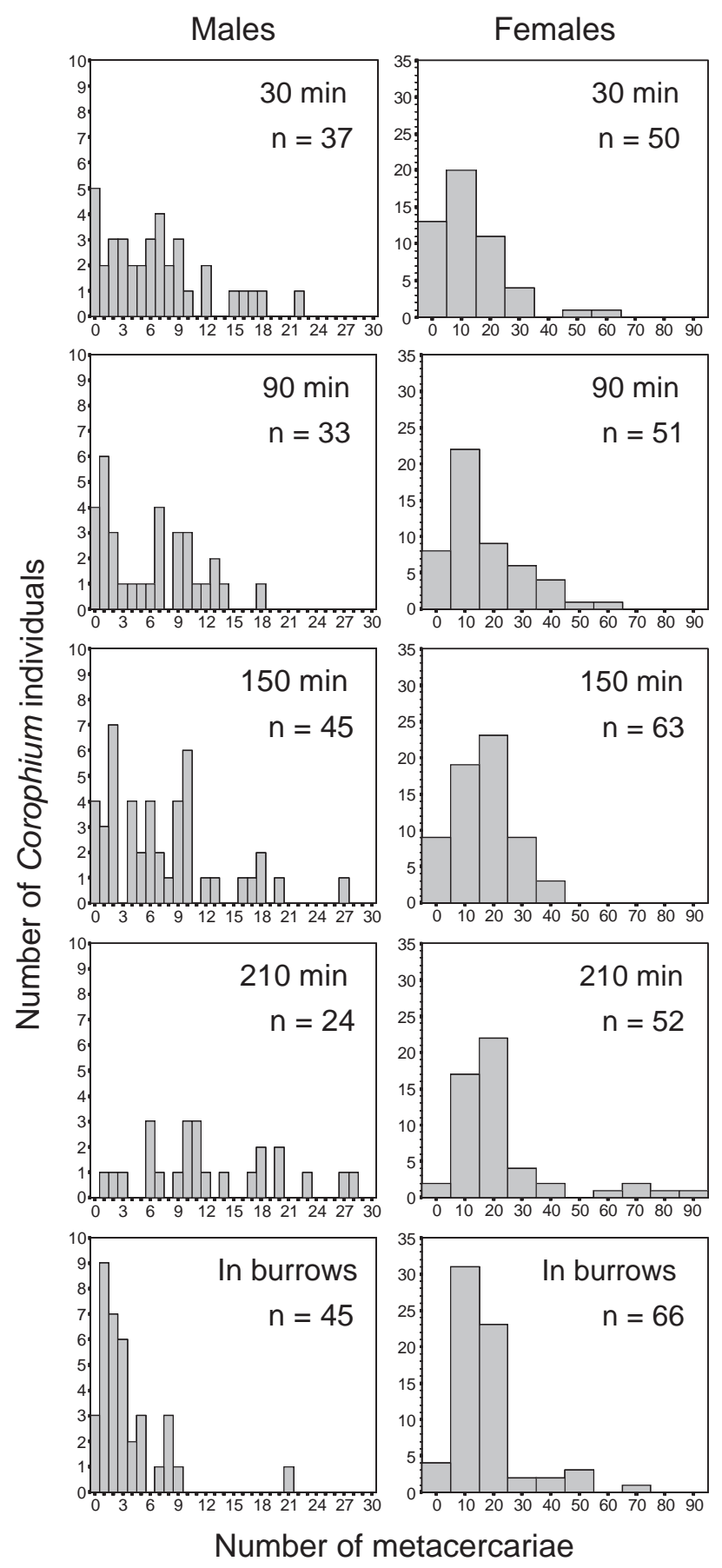

Fig. 2. Observed frequency distributions of the number of metacercariae in males (to the left) and females (to the right) Corophium volutator collected (1): four times after high tide (indicated by minutes after high tide) from the sediment surface and (2): once from burrows in the sediment (in burrows). 


\section{Results}

Microphallus claviformis was the most abundant parasite in both surface-active and burrowed Corophium volutator specimens of either sex (Table 1). It was present in all surface-active individuals and in $90 \%$ of the burrowed ones. The other microphallids (Maritrema subdolum + Microphallidae sp. no. 15, unidentified pre-infective metacercariae and Levinseniella sp.) contributed with about one third of the total number of metacercariae and were generally found in more than half of the population.

The density of surface-active $C$. volutator was negatively correlated with time (Fig. 1A, Spearman's rho $=-0.40, \mathrm{n}=40, \mathrm{p}<0.05)$, whereas the mean abundance of microphallid metacercariae in the surface-active specimens increased with time (Fig. 1B, Spearman's rho $=0.27, \mathrm{n}=355, \mathrm{p}<0.05)$. The frequency distributions of infections in males and females following high tide show that the number of individuals with fewer than 10 metacercariae per individual tends to decline with time (Fig. 2), which may explain the increasing parasite abundance among remaining surfaced individuals. The overall parasite prevalence was $96 \%$ and it did not differ significantly between the four samples of surfaced and the sample of burrowed amphipods (Pearson, $\chi_{4}^{2}=6.17$, ns). However, both surfaced male and female $C$. volutator were more heavily infected than burrowed specimens of either sex (Mann-Whitney test: males $\mathrm{z}=-5.018$, $p<0.001$; females $z=-2,138, p<0.05$; Fig. 2). This is

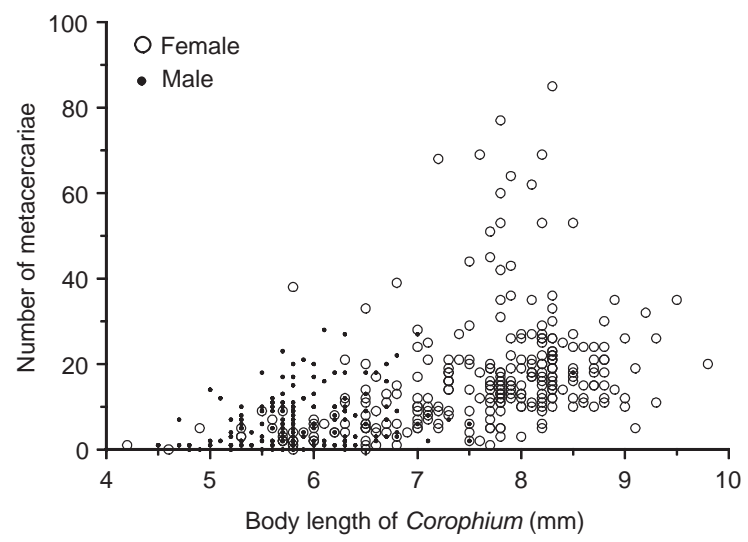

Fig. 3. Number of microphallid metacercariae in males (black dots) and females (white circles) of Corophium volutator as a function of body length. All samples combined.

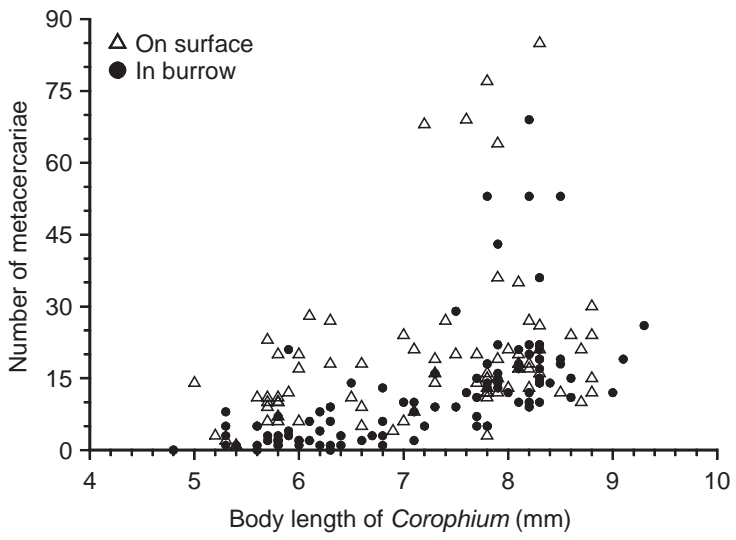

Fig. 4. Number of microphallid metacercariae in burrowed (black dots) and surfaced (white triangles) Corophium volutator as a function of body length. For surfaced amphipods, only specimens collected 210-250 min after high tide are included.

not due to size differences between specimens from the two sites. So, the average body lengths of males (5.8 $\mathrm{mm} \pm 0.14$; mean $\pm 95 \%$ C.I.) and females (7.2 $\mathrm{mm} \pm 0.25$, mean $\pm 95 \%$ C.I.) from the surface (sampled 210-250 min after high tide) did not differ from the burrowed specimens (males: $6.0 \mathrm{~mm} \pm 0.17$; females: $7.2 \mathrm{~mm} \pm 0.22$; mean $\pm 95 \%$ C.I.) (t-test for both males and females: $p>5 \%$ ).

The population of $C$. volutator was female-skewed (Table 1), but no significantly different sex ratio could be demonstrated among the four samples of surfaced and the sample of burrowed amphipods (Pearson, $\left.\chi_{4}^{2}=3.05, \mathrm{~ns}\right)$.

The parasite load was considerably higher in females than in males (Table 1, Fig. 2). Nearly 6\% of the females harboured more than 40 metacercariae (maximum was 85), whereas all males had less than 30 metacercariae each. This pattern is most likely a result of the size difference between males and females: the number of metacercariae increases significantly with length in both male (Spearman's rho $=0.334, \mathrm{p}<0.001, \mathrm{n}=175)$ and female amphipods (Spearman's rho $=0.541, \mathrm{p}<0.001, \mathrm{n}=282$ ), and females were generally larger than males (Fig. 3). Only $3.4 \%$ of the male population were longer than $7 \mathrm{~mm}$, whereas $32.3 \%$ of the females exceeded this size. Furthermore, sex specific accumulation of metacercariae is an unlikely explanation for the observed pattern as there was no difference between sexes regarding mean infection intensity in individuals of less than $7 \mathrm{~mm}$ length (t-test, $\mathrm{t}_{232}=-0.684$, ns). 


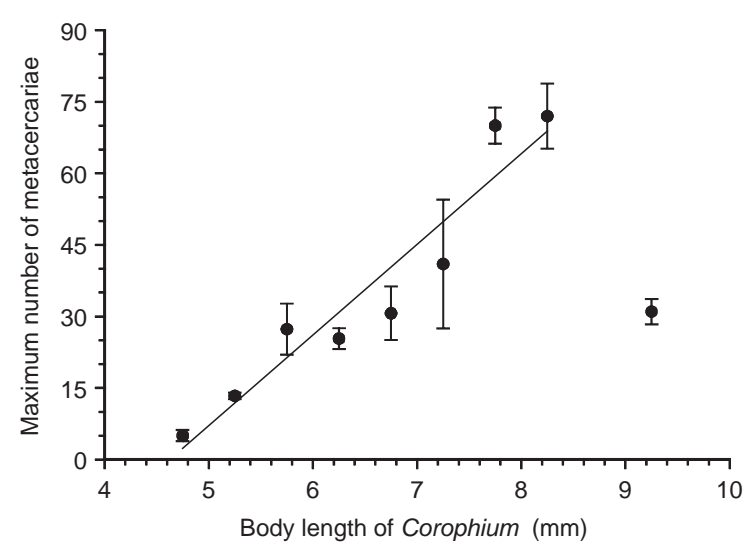

Fig. 5. Maximum number of microphallid metacercariae in Corophium volutator as a function of body length. For each length intervals of $0.5 \mathrm{~mm}$, the mean number of metacercariae ( \pm S.E.) for the three individuals with the highest parasite load is indicated. For individuals less than $8.5 \mathrm{~mm}$ in length, the relationship between maximum number of metacercariae and body length is linear (maximum number of metacercariae $=-88.0+19.0 *$ length, $r^{2}=0.79$, $\mathrm{n}=24)$.

Having demonstrated the absence of sex-specific accommodation of metacercariae between individuals from the surface and from the bottom, we can directly compare the intensity of metacercariae in the amphipods from the two sites as a function of their sizes (Fig. 4). For each interval of body length, the parasite load was significantly higher in surfaced than in burrowed amphipods (paired t-test: $\mathrm{t}_{55}=4.0, \mathrm{p}<0.001$ ) as an indication that the observed surface behaviour of C. volutator is related to the presence of large numbers of metacercariae.

Although the infection intensity generally increased with host size (Fig. 4), the maximum number of metacercariae harboured by the amphipods was substantially lower in the largest size group than predicted from the otherwise linear relationship between maximum parasite load and size in the smaller host individuals (Fig. 5).

\section{Discussion}

The present results demonstrate that Corophium volutator specimens crawling on the sediment surface at low tide harbour more microphallid trematodes on average than tube-dwelling specimens, and that the proportion of heavily infected individuals increases with time. The latter is most likely due to the burrow- ing of mainly lightly infected specimens as exposuretime increases, but surfacing of heavily infected individuals late in the low-tide period could be an additional factor (see Fig. 2). Hence, microphallids appear indeed to be one factor that may cause directly or indirectly - surface activity of $C$. volutator as laboratory experiments have previously suggested (Mouritsen and Jensen, 1997).

The behavioural change of infected amphipods is intensity dependent, and the intensity required to induce surface activity is positively related to host size (Fig. 4). However, because of (1) the considerable and overlapping variation in infection intensity in surfaced and burrowed amphipods, irrespective size group, and (2) the presence of heavily infected burrowed individuals, a threshold parasite-load above which the behavioural change is induced does not exist. This weakens the possibility that the surface behaviour is induced directly by the parasites, e.g. by the release of certain neurotransmitters or by encystment in specific behaviour-controlling nerve tissues (see Helluy, 1984; Helluy and Holmes, 1989). The surface behaviour may rather be the indirect result of the infection causing food deficiency, increased oxygen demand and/or obstruction of the locomotory apparatus. For instance, the volume of microphallid cysts increase up to 40-fold during development, and the nourishment for this growth must come from the host (Benjamin and James, 1987; Galaktionov et al., 1996). Consequently, infected amphipods may have an increased food demand, and relocation (i.e. surface activity) could be a way of obtaining unexploited food sources. Regarding oxygen demands, Mouritsen and Jensen (1997) showed that microphallid infections could result in gill anaemia, which in turn might reduce the efficiency of oxygen uptake. At low tide, the water contained in the burrows tends to become deoxygenated (Teal, 1959; Petersen and Johansen, 1967), and heavily infected hosts may therefore leave their burrows to reach higher oxygen tensions at the surface. Furthermore, probably as a result of the mechanical obstruction of muscle tissues and various internal organs, heavily infected specimens of $C$. volutator are less capable of bending and flexing their body and appendages (Meißner and Schaarschmidt, 2000; Damsgaard, 2002). This can interfere with the amphipods' ability to construct and enter burrows, and 
heavily infected specimens may therefore remain at the surface. Because the impact of the above-mentioned not mutually exclusive mechanisms will depend on individual nutritional and competitive status and the exact position of the metacercarial cysts within the body-cavity of the host individual, a narrow threshold infection intensity for the induction of behavioural change is unlikely to occur, as indeed observed.

Although the surface behaviour of infected amphipods thus appears to be pathological side-effects of infection, it may nonetheless be beneficial to the parasites, and therefore not selected against during the course of evolution. Waders, including Dunlins (Calidris alpina) as the most abundant bird predator of $C$. volutator in the Wadden Sea and known final host to microphallids (Deblock, 1980; Laursen and Frikke, 1984), feed during daytime low-tides preferentially by visual means on surface-active prey organisms (Zwarts and Wanink, 1993; Mouritsen, 1994). Hence, by forcing the host (directly or indirectly) to the surface during low tide, the parasites' transmission success will be substantially increased in comparison to when the infected hosts remain in their burrows. This holds true also if a substantial proportion of the surfaced amphipods (and their parasites) should be lost to epibenthic non-host predators during high tide (see Mouritsen and Poulin, 2003a; Thompkins et al., 2004).

Female C. volutator were found to accommodate more microphallid cysts than males, but this can be explained by their size difference. Among amphipods larger than $7 \mathrm{~mm}$, males account for less than 3\%. The size-dependent infection intensity is explainable by the age-size relationship (parasites accumulate with time) and by the expected relationship between size and ventilation rate. A higher flow of water through burrows is also bound to result in a higher flux of infective parasite larvae swimming in the water column (Mouritsen and Jensen, 1997).

The observed female-biased sex ratios among adults are the rule within populations of $C$. volutator, usually explained by different ratios among newly hatched specimens (Schneider et al., 1994) or by differential mortality on adult males (e.g. Boates and Smith, 1989). The male dominance among specimens less than $7 \mathrm{~mm}$ in our case excludes the former possibility. Because males are more surface active than females in their search for receptive tube-dwelling females, they are also more vulnerable to predators, and gradually the male population can be depleted.

A size-biased elimination of $C$. volutator specimens induced by parasites is also suggested by our data. The maximum cyst numbers increases linearly with body length and since the volume-length relationship in C. volutator is best described by a powerfunction, we would predict larger individuals to contain a disproportionally higher cyst number than smaller individuals. The opposite seems to be the case in particular for the largest $C$. volutator individuals (Fig. 5). This pattern suggests that selective mortality takes place on larger and more heavily infected specimens, and such selective mortality agents could easily be shorebirds at low tide and epibenthic predators (flatfish, crabs, shrimps) at high tide. Direct parasite intensity-dependent mortality could also be involved (Jensen and Mouritsen, 1992; Mouritsen and Jensen, 1997; Jensen et al., 1998; Meißner and Bick, 1999).

Our study shows that microphallid trematodes affect the behaviour of $C$. volutator, with possible implications not only for the parasites' life cycle but also the population dynamics of the amphipod. Many intra- and interspecific density-dependent processes may induce emigration from a site (Jensen, 1985; Flach, 1994), and migrants could indeed be specimens weakened by heavy parasite loads and hence inferior combatants in intra- and interspecifc interactions. As parasites may be a cryptic factor determining the outcome of many biotic processes it is advisable to include parasites in population and community studies (see Mouritsen and Poulin, 2003b).

\section{Acknowledgements}

The study was supported by a grant from the Carlsberg Foundation (K.N.M. and K.T.J.).

\section{References}

Benjamin, L.R., James, B.L., 1987. The development of the metacercaria of Maritrema linguilla Jäg., 1908 (Digenea: Microphallidae) in the intermediate host, Ligia oceanica (L.). Parasitology 94, 221-231.

Boates, J.S., Smith, P.C., 1989. Crawling behaviour of the amphi- 
pod Corophium volutator and foraging by Semipalmated Sandpipers, Calidris pusilla. Can. J. Zool. 67, 457-462.

Bowers, E.A., Bartoli, P., Russel-Pinto, F., James, B.L., 1996. The metacercariae of sibling species of Meiogymnophallus, including M. rebecqui comb. nov. (Digenea: Gymnophallidae), and their effects on closely related Cerastoderma host species (Mollusca: Bivalvia). Parasitol. Res. 82, 505-510.

Bush, A.O., Fernández, J.C., Esch, G.W., Seed, J.R., 2001. Parasitism: The Diversity and Ecology of Animal Parasites. Cambridge University Press, Cambridge.

Damsgaard, J.T., 2002. Transmissionseffektivitet og værtseffekter af microphallide trematod-arter i relation til Corophium volutator. M.Sc. Thesis, University of Aarhus, Denmark, unpublished (text in English).

Deblock, S., 1980. Inventaire des trematodes larvaires parasites des mollusques Hydrobia (Prosobranches) des côtes de France. Parasitologia 22, 1-105.

Dobson, A.P., 1988. The population biology of parasite-induced changes in host behavior. Quart. Rev. Biol. 63, 139-165.

Fish, J.D., Mills, A., 1979. The reproductive biology of Corophium volutator and C. arenarium (Crustacea: Amphipoda). J. Mar. Biol. Ass. UK 59, 355-368.

Flach, E.C., 1994. Does the activity of cockles, Cerastoderma edule (L.) and lugworms, Arenicola marina L., make Corophium volutator Pallas more vulnerable to epibenthic predators: A case of interaction modification? J. Exp. Mar. Biol. Ecol. 182, $265-285$.

Fredensborg, B.L., 2001. Digene trematoders (Microphallidae) tidsmæssige og rummelige fordeling i mellemværterne Hydrobia ulvae og Corophium volutator som function af forekomsten af slutværter (vadefugle) i en efterårsperiode. M.Sc. Thesis, University of Aarhus, Denmark (text in English).

Galaktionov, K.V., Malkova, I.I., Irwin, S.W.B., Saville, D.H., Maguire, J.G., 1996. Developmental changes in the tegument of four microphallid metacercariae in their second (crustacean) intermediate hosts. J. Helminth. 70, 201-210.

Helluy, S., 1984. Relations hôtes-parasites du trématode Microphallus papillorobustus (Rankin, 1940). III. Facteurs impliqués dans les modifications du comportement des Gammarus hôtes intermédiaries et tests de prédation. Annales de Parasitologie Humaine et Comparée 59, 41-56 (in French).

Helluy, S., Holmes, J.C., 1989. Serotonin, octopamine, and the clinging behavior induced by the parasite Polymorphus paradoxus (Acanthocephala) in Gammarus lacustris (Crustacea). Can. J. Zool. 68, 1214-1220.

Hicklin, P.W., Smith, P.C., 1984. Selection of foraging sites and invertebrate prey by migrant semipalmated sandpipers, Calidris pusilla (Pallas), in Minas Basin, Bay of Fundy. Can. J. Zool. 62, 2201-2210.

Jensen, K.T., 1985. The presence of the bivalve Cerastoderma edule affects migration, survival and reproduction of the amphipod Corophium volutator. Mar. Ecol. Prog. Ser. 25, 269-277.

Jensen, K.T., Mouritsen, K.N., 1992. Mass mortality in two common soft-bottom invertebrates, Hydrobia ulvae and Corophium volutator - the possible role of trematodes. Helgoländer Meeresunters. 46, 329-339.

Jensen, T., Jensen, K.T., Mouritsen, K.N., 1998. The influence of the trematode Microphallus claviformis on two congeneric intermediate host species (Corophium): infection characteristics and host survival. J. Exp. Mar. Biol. Ecol. 227, 35-48.

Jensen, K.T., Castro, N.F., Bachelet, G., 1999. Infectivity of Himasthla spp. (Trematoda) in cockle (Cerastoderma edule) spat. J. Mar. Biol. Ass. UK 79, 265-271.

Lauckner, G., 1983. Diseases of Mollusca: Bivalvia. In: Kinne, O. (Ed.), Diseases of Marine Animals. Biologische Anstalt, Helgoland, pp. $377-400$.

Lauckner, G., 1987a. Ecological effects of larval trematode infestation on littoral marine invertebrate populations. Int. J. Par. 17, 391-398.

Lauckner, G., 1987b. Effects of parasites on juvenile Wadden Sea invertebrates. In: Tougaard, S., Asbirk, S. (Eds.), Proc. 5th Int. Wadden Sea Symp.. The National Forest and Nature Agency and The Museum of Fisheries and Shipping, Esbjerg, pp. $103-121$.

Laursen, K., Frikke, J., 1984. The Danish Wadden Sea. In: Evans, P.R., Goss-Custard, J.D., Hale, W.G. (Eds.), Coastal Waders and Wildfowl in Winter. Cambridge University Press, Cambridge, pp. 214-223.

Margolis, L., Esch, G.W., Holmes, J.C., Kuris, A.M., Schad, G.A., 1982. The use of ecological terms in parasitology (report of an ad hoc committee of the American Society of Parasitologists). J. Parasitol. 68, 131-133.

Matthews, S.L., Boates, J.S., Walde, S.J., 1992. Shorebird predation may cause discrete generations in an amphipod prey. Ecography $15,393-400$.

McCurdy, D.G., Forbes, M.R., Boates, J.S., 1999a. Evidence that the parasitic nematode Skrjabinoclava manipulates host Corophium behavior to increase transmission to the sandpiper, Calidris pusilla. Behav. Ecol. 10, 351-357.

McCurdy, D.G., Forbes, M.R., Boates, J.S., 1999b. Testing alternative hypotheses for variation in amphipod behaviour and life history in relation to parasitism. Int. J. Par. 29, 1001-1009.

McCurdy, D.G., Forbes, M.R., Boates, J.S., 2000. Male amphipods increase their mating effort before behavioural manipulation by trematodes. Can. J. Zool. 78, 606-612.

Meadows, P.S., Reid, A., 1966. The behaviour of Corophium volutator (Crustacea: Amphipoda). J. Zool. 150, 387-399.

Meißner, K., Bick, A., 1999. Mortality of Corophium volutator (Amphipoda) caused by infestation with Maritrema subdolum (Digenea, Microphallidae) - laboratory studies. Dis. Aquat. Org. 35, 47-52.

Meißner, K., Schaarschmidt, T., 2000. Ecophysiological studies of Corophium volutator (Pallas, 1766) (Amphipoda) infested by microphallid trematodes. Mar. Ecol. Prog. Ser. 202, 143-151.

Meltofte, H., Blew, J., Frikke J., Rösner, H.U., Smit, C.J., 1994. Numbers and distribution of waterbirds in the Wadden Sea. Results and evaluation of 36 simultaneous counts in the Dutch-German-Danish Wadden Sea 1980-1991. IWRB Publication 34. Wader Study Group Bulletin 74, Special Issue. Common Secretariat for the Cooperation on the Protection of the Wadden Sea, IWRB, WSG, Svendborg, Denmark.

Moore, J., 2002. Parasites and the Behavior of Animals. Oxford University Press, Oxford.

Mouritsen, K.N., 1994. Day and night feeding in Dunlins Calidris 
alpina: choice of habitat, foraging technique and prey. J. Avian Biol. 25, 55-62.

Mouritsen, K.N., 2002. The parasite-induced surfacing behaviour in the cockle Austrovenus stutchburyi: a test of an alternative hypothesis and identification of potential mechanisms. Parasitology $124,521-528$.

Mouritsen, K.N., Jensen, K.T., 1997. Parasite transmission between soft-bottom invertebrates: Temperature mediated infection rates and mortality in Corophium volutator. Mar. Ecol. Prog. Ser. 151, 123-134.

Mouritsen, K.N., Poulin, R., 2003a. Parasitism, community structure and biodiversity in intertidal ecosystems. Parasitology 124, $101-117$.

Mouritsen, K.N., Poulin, R., 2003b. Parasite-induced trophic facilitation exploited by a non-host predator: a manipulator's nightmare. Int. J. Par. 33, 1043-1050.

Mouritsen, K.N., Jensen, T., Jensen, K.T., 1997. Parasites on an intertidal Corophium-bed: factors determining the phenology of microphallid trematodes in the intermediate host populations of the mud snail Hydrobia ulvae and the amphipod Corophium volutator. Hydrobiologia 355, 61-70.

Peer, D.L., Linkletter, L.E., Hicklin, P.W., 1986. Life history and reproductive biology of Corophium volutator (Crustacea: Amphipoda) and the influence of shorebird predation on popu- lation structure in Chignecto Bay, Bay of Fundy, Canada. Neth. J. Sea Res. 20, 359-373.

Petersen, J.A., Johansen, K., 1967. Aspects of oxygen uptake in Mesochaetopterus taylori, a tube dwelling polychaete. Biol. Bull. Mar. Biol. Lab., Woods Hole 133, 600-605.

Poulin, R., 1994. The evolution of parasite manipulation of host behaviour: a theoretical analysis. Parasitology 109, 109-118.

Schneider, S.D., Boates, J.S., Forbes, M., 1994. Sex ratios of Corophium volutator (Pallas) (Crustacea: Amphipoda) in Bay of Fundy populations. Can. J. Zool. 72, 1915-1921.

Teal, J.M., 1959. Respiration in crabs in Georgia salt marshes and its relation to their ecology. Physiol. Zool. 40, 83-91.

Thomas, F., Poulin, R., 1998. Manipulation of a mollusc by a trophically transmitted parasite: convergent evolution or phylogenetic inheritance? Parasitology 116, 431-436.

Thompkins, D., Mouritsen, K.N., Poulin, R., 2004. Parasite-induced surfacing in the cockle Austrovenus stutchburyi: adaptation or not? J. Evol. Biol. 17, 247-256.

Watkin, E.E., 1941. The yearly life cycle of the amphipod, Corophium volutator. J. Anim. Ecol. 10, 77-93.

Zwarts, L., Wanink, J.H., 1993. How the food-supply harvestable by waders in the Wadden Sea depends on the variation in energy density, body-weight, biomass, burying depth and behaviour of tidal-flat invertebrates. Neth. J. Sea Res. 31, 441-476. 